indicated. Multiplication involves the use of the tube $M$, the multiplicand being stated on the $D$ line, and the multiplier on the $R$ line. Products are added into the accumulator automatically.

Storage tube $B$ is a valuable auxiliary to the machine and is used for modifying instructions. Instructions can, of course, be modified by the normal processes ( $A$ and $M$, etc.) in the same way as numbers, but this is often inconvenient and wasteful of time and storage space. Therefore each instruction $(s, f)$ is preceded by a single digit called the $b$ digit. If $b=0$, the content of line $B O$ of $B$ (normally zero) is added into the present instruction as this instruction is written into the $P I$ line of $C$, that is, before this instruction is used. If $b=1$, the content of line $B I$ of $B$ is used in the same manner. Numbers are written into $B$ from the main electronic storage, exactly as they are written into $M$, say.

Loading between the magnetic and electronic stores, and vice versa, is at present achieved manually.

Immediate future development of the machine will include the provision of more lines on the $B$ tube, further extension of the capacity of electronic and magnetic stores as required, improved input and output facilities, and automatic interchange of information between electronic and magnetic stores.

I wish to acknowledge my indebtedness to Prof. M. H. A. Newman, and Mr. A. M. Turing for much helpful discussion of the mathematical requirements of digital computing machines; and to Mr. G. C. Tootill, who has collaborated in the design of the machine.

${ }^{1}$ Williams, F. C., and Kilburn, T., J. Inst. Elect. Eng., 96, Pt. III, No. 40 (March 1949).

${ }^{2}$ Unpublished work by J. C. West and G. E. Thomas. For a description of a similar system, see Booth, A. D., Electronic Eng. (July 1949). silliams, F. C., J. Inst. Elect. Eng., 98, Pt. IIIA, 303 (1946).

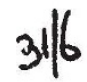

\section{FORESTS AND MAN}

A SERIES of five papers afder the picte of "Forests and Man" were read fforing the British Association meptifo in Newcasto on septem. ber 5 at a compined fireting of Siedion (Botany) and $\mathrm{K}^{*}$ (Forest fy. O Prof. H. S.) thampion, chairman of Seotivg $K_{i}^{*}$, presided.

The efriler papers were chiefly concerned with the history of British forests, and the later ones dealt with forest conservation. Dr. K. B. Blackburn outlined the history of the study of prehistoric forests and showed how the technique of pollen analysis, based on the counting of pollen grains preserved in the peat, had proved a tool of progressively increasing usefulness in revealing the details of forest history. The details for northern England were illustrated from the results of the study of a deep peat from Broadgate Fell, Northumberland, with continuous deposits from the end of the ice age up to present times. Here the graphs of pollen percentages showed features similar to those described by Dr. H. Godwin for East Anglia : first, a forest of birch yielding somewhat to pine as the hazel comes into prominence; then elm and oak appear, followed by a conspicuous rise of alder in a country now dominated by forest; later elm falls off; and afterwards a decline in tree cover is shown by proportionally large amounts of the pollen of herbaceous plants. The northern diagram differs, however, in having, throughout, larger quantities of birch and much smaller quan- tities of oak. Lime is very poorly represented, and beech and hornbeam are absent. In other northern deposits the percentages of pollen of pine, elm and oak may differ considerably, but the general trend of the curves for individual trees remains the same and may safely be put down to climatic changes.

Dr. Verona Conway introduced the question of the influence of man on the forests as shown by pollen analyses from three different localities. She first described how Iverson correlated charcoal layers found in Danish peats with changes in the vegetation : a fall in amount of tree pollen due to the fire was followed by a rise in hazel, birch and alder, at the expense of oak, with accompanying weeds of cultivation, such as ribwort plantain, and some cereal grains. Later, oak recovered. This was associated with the activities of the Neolithic farming people. Her second example was from Dr. Godwin's work at Hockham Mere, Breckland. Here, at the horizon where elm falls off in quantity, the sudden increase of herbaceous pollen indicates a reduction in forest at a period earlier than normal. This again can be associated with the arrival and activities of Neolithic man. Lastly, Dr. Conway referred to her own work at Ringinglow Bog, near Sheffield, where the sudden increase of herbaceous pollen was later, and by careful calculation of depths, worked out as being at A.D. 1100-1200. This probably corresponds to the appearance of sheep farming associated with the wool trade carried on by the nearby Cistercian monastery.

Dr. Frank Darling followed with a paper on "The History of the Scottish Forests". He explained that, though the fate of the early forests was due to the encroachment of the mosses, the disappearance of the later forest could be put down to a series of human activities. First, the Hallstadt Celts cleared around their living places on the coast and eastern plain, and the Romans destroyed trees as a military measure. Forests in the north and west remained; the Vikings in the ninth to the eleventh centuries burnt these from the coast; but perhaps the greater destruction was in the exploiting of forests to obtain timber for shipbuilding, and later charcoal for iron smelting.

The southern uplands were cleared in the fifteenth century with the introduction of sheep farming. North of the Clyde this did not begin until 1760, and in Ross not until early in the nineteenth century. Lastly, forest was cleared to get rid of wolves and to round up Jacobite fugitives. Nowadays, only small areas of natural birch and oak wood remain, and the pine forest with characteristic undergrowth is reduced to a few hundred acres.

Planting began in the early eighteenth century when the Countess of Seafield put in twenty million trees, but even now planted forests cover a relatively small area. Dr. Darling urged that the time is ripe for the land to go back to a forest continuum, as the sheep have been there too long.

Dr. C. Jacquiot, of Fontainebleau, then considered the question of forest conservation. He contrasted the traditional definition used in the Forest School at Nancy, "the keeping of the forest identical to itself forever as considered in time and space", with the simple one of maintenance of forest on wooded land.

Study of the biological reserves in the Forest of Fontainebleau has helped to arrive at a scientific basis of conservation of the less rigorous type. This forest reserve consists of various ages and species of 
trees, with characteristic undergrowth. The fallen trees have their own flora and fauna with very precise needs and associations. In undisturbed forest there is little mineral loss, for all is returned to the soil. High forest under tree selection management looks very similar, but lacks the flora and fauna associated with fallen logs. The community may, however, be as stable as the natural one if no species is felled to abnormal scarcity and the stand is not over-cut. This and also even-aged high-forest management chiefly differ from natural forest in that the forester removes dead wood, instead of the fungi and insects doing so. The removal of the timber in temperate climes does not deplete the mineral reserves unduly, since the ash content of wood itself is low. On the other hand, small-sized branches have a greater mineral content owing to the higher proportion of living cells, and their removal may, for example, deplete the phosphorus content of the soil unduly. Dr. Jacquiot finally concluded that the high-forest system, with as long a revolution as possible, shows itself as the best method of forest conservation; coppice with standards can be used on good soils, but ordinary coppice is fundamentally a bad system.

Dr. R. Maclagan Gorrie discussed the Western Punjab to illustrate the necessity for conservation of forests. He thinks that forests do not actually alter the rainfall but they help to retain the moisture, and on the removal of forest the place becomes too dry. Crops such as tea, coffee and cocoa do not take the place of forest as the plants are widely spaced and so the ground becomes liable to erosion. Dr. Gorrie illustrated by lantern slides some conspicuous failures in conservation due to grazing, fire and continuous lopping of branches. Re-afforestation in arid countries is difficult but not impossible. Methods of proved worth are trenching along contours, terracing with the aid of bulldozers, check dams in the nullahs and other ways of controlling mun-off of water. Shelter belts and hedgerows are necessary. Tamarix articulata and Melia azedarach are useful for this purpose.

For the actual planting, the land can be prepared by kans grass (Saccharum spontaneum) or barber grass (Eulaliopsis binata), and then shisham (Dalbergia sissoo) follows. In one case, a Mexican species Prosopis juliflora planted many years ago has proved a most successful forest tree.

Kathleen B. BluackbuRn

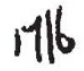

\section{UNIVERSITY OF MALAYA}

$\mathrm{O}$ October 8 the University of Malaya was officially founded, an $\$ \mathrm{Mr}$. Malcolm MacDonald, Governor-General of Mraya, installed as the first chancellor. The coloturful ceremonies at Singapore and the messag of goodwill from the universities throughout the dommonwealth, welcoming this latest arrival inte the British academic family, mark the end of a boinning that dates from 1819. Stamford Raffles, in the vision he had of Singapore, urged that it should include a centre of learning and intellect, a "monument of light". "Shall we not consider it one of our first duties to afford the means of education to surrounding countries and thus render our stations not only the seats of commerce but of literature and the arts ?" Raffles Institution, now a secondary school, and Raffles Museum and Library, which has been a government establishment since 1878, repre- sent parts of the realization of Raffles's vision; but the direct parentage of the new University is to be found in the College of Medicine and Raffles College.

The College of Medicine, opened in 1905, adopted the name King Edward VII Medical School in 1912, altered to College in 1921. A government institution, it has been an integral part of the government medical services throughout its existence. It early won a high reputation, and its medical diploma has been recognized by the General Medical Council as a registrable qualification since 1916. It has had a dental school since 1929, the awards of which are also registrable qualifications. The College has received important endowments, including that of the chair of physiology from the King Edward VII Memorial Foundation in 1912 and of the chairs of bacteriology and biochemistry from the Rockefeller Foundation in 1925. By 1939 it had eleven professors and thirty-five other teaching staff, and a student body of 158 .

Raffles College was founded to commemorate the centenary of Singapore "with a view to laying securely the foundations upon which a University may in course of time be established". It was opened in 1928, as a non-government institution, and has provided diploma courses in science and arts, including economics, and postgraduate courses in education. In 1941 it had seven chairs and seven other teaching posts, and a student body of more than three hundred.

A commission on higher education in Malaya was appointed by the Secretary of State for the Colonies in 1938. Its members, Sir William McLean and Dr. H. T. Channon, presented their report in June 1939, recommending that the College of Medicine and Raffles College should be fused into a University College of Malaya. Before decisions could be reached on the Commission's proposals, the War began, Malaya was in enemy occupation, Raffles College was used as Japanese military headquarters and the College of Medicine converted into a centre for the large-scale production of vaccine and serum. Most of the staff were captured and interned; school education almost ceased for four years. After liberation in September 1945, the surviving staff achieved a very rapid rehabilitation of the two Colleges; the College of Medicine was opened in June 1946, and Raffles College four months later, after the Allied military authorities had vacated the premises. The structures of the buildings of both Colleges were intact; indeed, the Japanese had usefully added a wing to Raffles College. The libraries had survived; but much of the equipment and furnishings had gone.

During the War, university education in the British Colonies had been reviewed by an authoritative commission under the chairmanship of Sir Cyril Asquith. A member of the Asquith commission, Dr. (now Sir) Raymond Priestley, vice-chancellor of the University of Birmingham, who had also served on its West Indies committee, was invited to visit Malaya in 1946 to explain the principles and policy formulated by the commission and to advise on their local application. As a result of his visit, a principaldesignate of the proposed university college, Dr. G. V. Allen, formerly principal of the College of Medicine, was appointed, and a full commission, under the chairmanship of Sir Alexander M. CarrSaunders, visited Malaya in March-April 1947. The commission decided that the two Colleges had so firmly established their academic standards that it 